\title{
Growth, Yield and Biochemical Responses in Barley to DAP and Chitosan Application Under Water Stress
}

\author{
Abdel Rahman M. Al-Tawaha ${ }^{1 *}$, Nusrat Jahan², Nidal Odat ${ }^{3}$, \\ Ezz Al-Dein Al-Ramamneh ${ }^{4}$, Abdel Razzaq Al-Tawaha ${ }^{5}$, \\ Yousef M. Abu-Zaitoon ${ }^{1}$, Khalid Fandi ${ }^{1}$, Mohammad Alhawatema ${ }^{6}$, Amanullah', \\ Abdur Rauf ${ }^{8}$, Mohammad Wedyan ${ }^{9}$, Mohammad Ali Shariati ${ }^{10}$, Ali M. Qaisi ${ }^{11}$, \\ Imran ${ }^{7}$, Khaled Tawaha ${ }^{11}$, Munir Turk ${ }^{12}$, Samia Khanum ${ }^{13}$ \\ 1 Department of Biological Sciences, Al Hussein Bin Talal University, P.O. Box 20, Ma'an, Jordan \\ 2 Department of Botany, Faculty of Life Sciences Aligarh Muslim University, Aligarh-202002, UP, India \\ 3 Department of Medical Laboratories, Faculty of Science, Al-Balqa Applied University, 19117, Al Salt, Jordan \\ 4 Department of Agricultural Sciences, Al-Balqa Applied University, Al-Shouback College, Al-Shoubak, Jordan \\ 5 Department of Crop Science, Faculty of Agriculture, Universiti Putra Malaysia, 43400, Serdang, Selango, \\ Malaysia \\ 6 Department of applied biological science, Faculty of Science, Tafila Technical University, Tafila, Jordan \\ 7 Agronomy Department, The University of Agriculture Peshawar, Pakistan \\ 8 Department of Chemistry, University of Swabi, Anbar, Khyber Pakhtunkhwa, Pakistan \\ 9 Department of Biology and Biotechnology, Faculty of Science, the Hashemite University, Zarqa, Jordan \\ ${ }^{10}$ Laboratory of Biocontrol and Antimicrobial Resistance, Orel State University Named After I.S. Turgenev, \\ 302026 Orel, Russia \\ ${ }^{11}$ Department of Pharmaceutical Sciences, School of Pharmacy, University of Jordan, Amman, Jordan \\ ${ }^{12}$ Department of Plant Production, Jordan University of science and Technology, Irbid, Jordan \\ ${ }^{13}$ Department of Botany, University of the Punjab, Lahore, Pakistan \\ * Corresponding author's e-mail: abdel-al-tawaha@ahu.edu.jo
}

\begin{abstract}
The present investigation was aimed at enhancing the quality and productivity of barley by the fertilizer and chitosan application. The field experiments were conducted in the northern region of Jordan, under the rain fed conditions in the main growing seasons of 2014/2015 and 2015/2016. The experiment was conducted in a well-designed split-plot having three replications and two fertilizer levels ( 0 and $100 \mathrm{~kg} \cdot \mathrm{ha}^{-1} \mathrm{DAP}$ (Diammonium phosphate $46 \%$ $\left.\mathrm{P}_{2} \mathrm{O}_{5}\right)$. Chitosan, in three different concentrations $\left(0,5\right.$, and $\left.10 \mathrm{~g} \cdot \mathrm{L}^{-1}\right)$, was randomly applied to all fertilized plots as subplot treatments. The results revealed the highest seed dry weight (5.8 g per plant) in the plants treated with $100 \mathrm{~kg} \cdot \mathrm{ha}^{-1}$ of DAP, while the lowest (5.2 g per plant) was recorded in the control which exhibited an increase of about $10 \%$. However, other parameters, namely the number of grains, number of spikes, and number of grains were also found to be influenced by the chitosan treatment. Significant variation $(\mathrm{P}<0.01)$ were also high between the lines in the presence and absence of chitosan application. The highest number of grain yield, number of spikes, and grains/spike were found by the foliar treatment of $10 \mathrm{~g} \cdot \mathrm{L}^{-1}$ chitosan to barley plants at the tillering stage. Similarly, the grain quality, particularly with respect to protein and starch, was found to be enhanced significantly over control. The highest protein (12.6\%) and starch (62.3\%) were obtained with $100 \mathrm{~kg} \cdot \mathrm{ha}^{-1} \mathrm{DAP}$ fertilizer level mixed with $10 \mathrm{~g} \cdot \mathrm{L}^{-1}$ chitosan. Hence, based on results, it can be concluded that the fertilizer level $100 \mathrm{~kg} \cdot \mathrm{ha}{ }^{-1} \mathrm{DAP}$ combined with $10 \mathrm{~g} \cdot \mathrm{L}^{-1}$ chitosan is economically best and recommendable for improving the quality and productivity of barley in the northern region of Jordan.
\end{abstract}

Keywords: barley, DAP, chitosan, fertilizer, Jordan. 


\section{INTRODUCTION}

Barley (Hordeum vulgare L.) is the fourth most popular crop around the globe in terms of cereal production, following maize, rice and wheat (Yangcheng et al., 2016). It is also utilized as feed, food and other malt-based food products (Al-Tawaha et al., 2002; Al-Tawaha and Turk, 2002; Al-Tawaha et al., 2003). Barley is acknowledged extensively as a part of a healthy diet, especially in some western nations (Baik and Ullrich, 2008), because the grain contains a great amount of glucan content, whereas the starch stored in the endosperm ranges from 62 to $77 \%$ of whole grain dry weight (Asare et al., 2011). It is cultivated under the dry land conditions in northern Jordan, west Asia and Africa where inadequate rainfall limits the production (Tawaha, 2000). The barley production under the dry land condition is better than other cereal crops such as wheat and oats (Al-Tawaha and Al-Ghzawi, 2013; Al-Ajlouni et al., 2009).

In general, macronutrients play an essential role in different biochemical pathways in both plants and animals; therefore, they are required in considerable amount for their survival and growth. Furthermore, these are also found to boost the growth and yield of numerous crops (Morgan and Connolly, 2013) and also play a vital role in barley production. On the basis of their functions, macronutrients like $\mathrm{N}, \mathrm{P}$, and $\mathrm{K}$, were categorized as primary macronutrients (García et al., 2003; Rowley et al., 2012).

Nitrogen is an essential element for plants, as they require an adequate supply of this nutrient for their growth. Moreover, it is also a crucial part of the amount of chlorophyll pigments, which is required for the photosynthetic process (Nursu'aidah et al., 2014) and assists in promoting the productivity of fruit and seeds along with the speedy plant growth as well as the productivity of crops (Mengel and Kirkby, 1987; Marschner, 1999).

However, phosphorus performs an important role in maintaining all the physiological and biochemical processes of plants (Lott et al., 2000). The amount of phosphorus ranges from $0.05 \%$ to $0.50 \%$ in total dry weight of any crop (Marschner, 1999), as an ingredient of DNA, RNA, and ATP (Brown and Weselby, 2010). It is recognized as an essential component required for the proper growth and development of plants. Although its quantity in the soil is generally low, it is extensively applied exogenously in the form of organic phosphate to enhance the crop productivity and yields (Huang et al., 2011). It is also an important constituent of various metabolic processes, such as photosynthesis, respiration, storage, energy transfer, cell division, cell expansion and many more in plants. On the other hand, phosphorus is associated with the growth factor such as improved root growth, increased stem strength, improved flower formation and seed production, inducing early maturity, improved nitrogen fixation in legume, and increased resistance to pests. Tawaha et al., (2000) recorded that nitrogen $(\mathrm{N})$ and phosphorus $(\mathrm{P})$ are regarded as the principal macronutrients which influence the level and quality of crop yields and can diminish the agricultural production considerably in most regions of the world.

Chitosan is a natural polysaccharide, derived from N-deacetylation of chitin, an important component of the crustacean shells (Orgaz et al., 2011). Chitosan and its derivatives possess great potential for agricultural use and improving crop production because they are non-toxic, biodegradable, and environment-friendly (Chandrkrachang, 2002; Sarathachandra et al., 2004). Many studies showed that chitosan is beneficial in protecting plants against the oxidative stress (Teran and Singh, 2002) and enhancing plant growth (Gornik et al., 2008) in different crops. For both LCOs and chitosan, it is thought that the plant adaptive response is owed to the perception by plants due to their constitution of chitin, which is also the main component of the cell wall in fungal pathogens (Al-Tawaha et al., 2005).

Recently, there has been an increasing concern in using natural elicitors for promoting the plant growth, development, productivity and its overall improvement (Patkowska et al., 2006; Sereih et al., 2007; Gornik et al., 2008). Al Tawaha et al., (2006) stated that elicitors have been used to enhance the amount of essential phytochemicals in different plants species and to enhance the plants resistance to numerous diseases (Kim, 2005). According to Al-Tawaha et al., (2005), the soybean responses to elicitors while observing the effects when plants distinguished particular biochemical molecules or structural components that represent a foreign pathogen. This leads to the conclusion or the increase of the phenyl-propanoid pathway, following an enhanced isoflavones production.

As reported by Abera et al., (2011) generally, the productivity of barley is low especially due 
to the conventional methods of crop production and poor soil fertility. Nitrogen is regarded as the most important factor in the production of cereals. Barley crop responds significantly to the changing nitrogen levels. Still, there has been limited field investigation available on the scheduling of $\mathrm{N}$ fertilizer and chitosan which influences both the grain yield and grain quality.

Furthermore, the timing of their treatment has a considerable effect on the yield and quality of the crop. Following these views, a field experiment was conducted to determine the impact of varying levels of DAP and chitosan and their scheduling on barley under different growing seasons under the semi-arid condition in northern region of Jordan.

\section{MATERIALS AND METHODS}

The experimental trials were conducted in the northern part of Jordan, under the rainfed conditions during 2014/2015 and 2015/2016 growing seasons. The experiment field is located in the Irbid governorate at $32^{\circ} 33^{\prime} \mathrm{N}$ latitude, $35^{\circ} 51^{\prime} \mathrm{E}$ longitude and $589 \mathrm{~m}$ above sea level (Al-Ghzawi et al., 2018). The location of the experiment was characterized by the Mediterranean characteristics, in which the winter is mildly rainy, whereas the summer is hot and dry.

The soil chemical and physical properties for the experimental site at North part of Jordan are presented in Table 1. In the present study, a random design with split plot was used with 3 replications each. Th fertilizer applications $(0$ and $100 \mathrm{~kg} \mathrm{ha}^{-1}$ DAP (Diammonium phosphate $46 \% \mathrm{P}_{2} \mathrm{O}_{5}$ ) were randomly allocated to the major plots in each replicate. The chitosan doses $(0$, 5 , and $10 \mathrm{~g} \mathrm{~L}^{-1}$ chitosan) were also given to each fertilizer plot, preparing the sub-plot treatments. Chitosan was made from crab shells (Sigma-Aldrich, Mississauga, ON) applying the method earlier affirmed by Tawaha et al., (2005). The sowing of seeds was done by hand at a spreading rate of $100 \mathrm{~kg} \mathrm{ha}^{-1}$ on 15th and 19th November during $2014 / 2015$ and 2015/2016 growing seasons, respectively. The variables that were practiced for the experiment included grain yield, spikes number of per plant, grains number per spike, length of spike and plant height. At maturity, the plants were harvested on 5th and 10th June of 2014/2015 and 2015/2016 growing seasons, respectively. In each of the three central rows, the plants in a $1-\mathrm{m}^{2}$ quadrate were clipped at $10 \mathrm{~cm}$ above the earth surface. The starch content of the grains was measured following the method described by He (1985). The protein content of the samples was determined by the micro-Kjeldahl distillation method of AACC (2000). The experiment involved the use of MSTAT-C software (Michigan) which was employed for all analyses. Each piece for this experiment was analyzed in a randomized total block pattern (RCBD) with the split-plot design (Steel and Torrie, 1980).

\section{RESULTS AND DISCUSSIONS}

The effect of chitosan, DAP (diammonium phosphate $18 \% \mathrm{~N}$ and $46 \% \mathrm{P}_{2} \mathrm{O}_{5}$ ) applications on barley yield as well as yield and quality related traits were studied at the northern part of Jordan during 2014/2015 and 2015/2016 seasons. The impact of the two agents was investigated on various yield parameters such as the number of spikes per plant, number of grains per spike, grain yield and thousand-grain weight as well as on protein and starch contents. The data were collected for all the above-mentioned characters and subjected to a statistical analysis of variance to identify the significant differences among the applications (i.e., fertilizer-chitosan treatments). The main outcomes were evaluated in the absence of significant interplays between treatments. The analyses of variances for yield and yield components are summed in table 2 . The data shown resulted from the F-tests performed to examine major and interactive effects. Additionally, the effects of two agents on the protein and starch contents were estimated during the two growing seasons and shown in table 3 . The total annual precipitation during the 2014/2015 growing season was higher (494 mm) than that during 2015/2016, amounting to $386 \mathrm{~mm}$. Moreover, the rainfall during the following growing season was lower in comparison to the first growing season and this drop resulted in the lower grain yield.

\section{Effects of DAP (Diammonium phosphate $46 \% \mathrm{P}_{2} \mathrm{O}_{5}$ ) on yield components, grain yield and phenological traits}

The seed yield of barley is influenced by many yield components such as spike length, spike width, number of grains per spike, number of spikes per plants. The highest seed dry weight 
$5.8 \mathrm{~g}$ per plant was observed in the plots on which $100 \mathrm{~kg} \mathrm{ha}^{-1}$ of DAP was applied, while the lowest $5.2 \mathrm{~g}$ per plant was seen in the control which showed an increase of about $10 \%$. The studies conducted by various researchers (Nikus et al., 2004) showed that the application of fertilizer significantly improves the growth and yield traits of various crops. Phosphorus is one of the most essential macro nutrients that significantly affects the growth and productivity of many crops (Turk and Tawaha, 2001; Tawaha and Turk, 2002a; Turk and Tawaha, 2002; Tawaha et al., 2003; Turk et al., 2003; Nikus et al., 2004; Tawaha and Turk, 2004; Turk et al., 2004). The number of spikes per plant is one of the main features contributing to the seed yield. The spike numbers were affected with DAP application significantly, the highest spike number (2 spikes per plant) was observed in the plots with the treatment of $100 \mathrm{~kg} \mathrm{ha}^{-1}$ of DAP while the lowest (1 spike per plant) was recorded in the control, which showed an increase of about $50 \%$. This finding agrees with the results of other studies, who found that the DAP fertilizer results in a higher spike number and it was significantly increased along with the rates of fertilizer (Tawaha, 2000). The two traits such as number of grains per spike and 1000 grain weight can be regarded as the two important crop variables that affected the grain yield per plant. The number of grains per spike and 1000 grain weight were affected by fertilizer treatment (Table 1). Further, the highly significant differences $(\mathrm{P}<0.01)$ were observed among the treatments with and without the fertilizer application. The maximum number of spikes per plant and 1000 seed weight were shown in the barley plants applied with $100 \mathrm{~kg} \mathrm{ha}^{-1}$ of DAP (Diammonium phosphate 46\% P2O5).

The application of DAP fertilizer (Diammonium phosphate $46 \% \mathrm{P}_{2} \mathrm{O}_{5}$ ) showed a significant effect on plant height, the maximum (tallest) plant with mean plant height $77 \mathrm{~cm}$ was obtained in the plots on which $100 \mathrm{~kg} \mathrm{ha}^{-1}$ of DAP was applied, while the minimum (shortest) with $66 \mathrm{~cm}$ was recorded under the control which exhibited a rise of about $14 \%$. This unusual raise in plant height with the increase in the DAP levels might be due to their synergistic effect of increased nutrient using capabilities. These outcomes are in good accordance with other investigations that revealed highly significant differences in plant height of barley subjected to high amounts of fertilizers compared with zero application (Tawaha et al., 2000). On the basis of these results, it can be concluded that the plant height is an important parameter of yield in barley as the taller plant usually bears more spikes and contributes enhanced yield (Tawaha et al., 2002). The spike length was affected with fertilizer significantly, the highest mean spike length $(7.0 \mathrm{~cm})$ was shown in the plots treated with $100 \mathrm{~kg} \mathrm{ha}^{-1}$ of DAP, while the lowest $(6.0 \mathrm{~cm})$ was recorded in the control which showed an increase of about $14 \%$. On the other hand, days to heading were not affected by fertilizer treatment and there were no significant differences $(\mathrm{P}<0.01)$ among the plants applied with and without fertilizer.

\section{Effects of chitosan on yield components, grain yield and phonological traits}

Chitosan was found to affect the grain yield per plant (Table 2 ). There were also highly significant differences $(\mathrm{P}<0.01)$ among the treatments with and without chitosan. The maximum grain yield per plant was achieved in the foliar application with $10 \mathrm{gL}^{-1}$ chitosan at the tillering stage. Chamnanmanoontham et al. (2015) observed an increased growth of rice seedlings with chitosan application by the gene expression system among the nucleus and chloroplast. Chitosan can improve the plant growth through their influence in thejasmonic acid pathway (Doares et al.,1995). As recorded by Sembdner and Parthier (1993), jasmonic acid regulates the water use by plants and causes the closing of the plant's stomata and decreased transpiration. On the other hand, Bittelli et al. (2001) affirmed the decreased transpiration and lowered the water usage by $26-43 \%$ in pepper plants following the foliar application of chitosan. Similar effects were also observed by Mondal et al. (2016) who recorded enhanced morpho-physiological traits and yield after the foliar treatment of chitosan at early stages in summer

Table 1. Chemical and physical properties of soil in the experimental sites at Northern part of Jordan

\begin{tabular}{|c|c|}
\hline Chemical and physical properties & North Jordan \\
\hline $\mathrm{P} \%$ & 1.18 \\
\hline $\mathrm{K} \%$ & 1.80 \\
\hline $\mathrm{CaCO}_{3} \%$ & 1.70 \\
\hline $\mathrm{N} \%$ & 0.1 \\
\hline $\mathrm{PH}$ & 7.0 \\
\hline E.C (ds/m) & 0.45 \\
\hline Clay & 54.2 \\
\hline Silt & 33.8 \\
\hline Sand & 12.00 \\
\hline
\end{tabular}


Table 2. Yield and yield component of barley plants as affected by the fertilizer and chitosan application

\begin{tabular}{|l|c|c|c|c|}
\hline \multicolumn{1}{|c|}{ Growing seasons } & $\begin{array}{c}\text { Grain yield per plant } \\
(\mathrm{g})\end{array}$ & $\begin{array}{c}\text { Number of spikes per } \\
\text { plant }\end{array}$ & $\begin{array}{c}\text { Number of grains per } \\
\text { spike }\end{array}$ & 1000 grain weight (g) \\
\hline $2014 / 15$ & 6.00 & 2.0 & 28.3 & 52 \\
\hline $2015 / 16$ & 5.00 & 1.0 & 22.3 & 45 \\
\hline LSD $(0.05)$ & 0.6 & 0.7 & 1.5 & 2.3 \\
\hline Fertilizer application & & & & 46 \\
\hline 0 & 5.2 & 1.0 & 23.3 & 51 \\
\hline $100 \mathrm{~kg} \mathrm{ha}^{-1}$ DAP & 5.8 & 2.0 & 27.3 & 7.0 \\
\hline LSD $(0.05)$ & 0.5 & 1.0 & 6.0 & 46 \\
\hline Chitosan treatment & & & & 49 \\
\hline Control & 5.3 & 1.5 & 24.0 & 51 \\
\hline $5 \mathrm{~g} \mathrm{~L}^{-1}$ chitosan & 5.5 & 1.5 & 25.5 & 4.0 \\
\hline $10 \mathrm{~g} \mathrm{~L}^{-1}$ chitosan & 5.7 & 2.0 & 26.5 & $\mathrm{NS}$ \\
\hline LSD $(0.05)$ & 0.3 & 0.6 & 0.6 & $\mathrm{NS}$ \\
\hline Fert X Chit & $\mathrm{NS}$ & $\mathrm{NS}$ & & \\
\hline
\end{tabular}

tomato (Solanum lycopersicum). Furthermore, Mondal et al. (2016) described that the foliar treatment with chitosan increases almost all of the morphological (plant height, number of leaves per plant), growth (total dry mass per plant, absolute and relative growth rate), biochemical (nitrate reductase and photosynthesis) and yield attributes (number of fruits per plant and fruit size) in Okra. In our study, the chitosan treatment significantly affected the number of spikes per plant (Table 3). The differences among the treatments with and without chitosan were shown to be highly significant $(\mathrm{P}<0.01)$. The maximum number of spikes per plant was reported with $10 \mathrm{~g} /$ chitosan as the foliar application at the tillering stage of the plant. Farouk et al. (2008) reported that chitosan provides top outcome in foliar application, such as greater vegetative growth and enhancement in the fruit quality. The number of grains per spike can be considered as one of the important crop variables that affected the grain yield/plant.

The number of grains per spike was also affected significantly $(\mathrm{P}<0.01)$ by the chitosan application (Table 2). The maximum number of grains per spike was obtained with the foliar application of $10 \mathrm{~g} \mathrm{~L}^{-1}$ chitosan at the tillering stage. These outcomes are in agreement with the other studies which showed that the chitosan use significantly improved the number of grain per spike and grain yield as compared to that in control (Behboudi et al., 2018). On the other hand, 1000 grain weight ( $\mathrm{g}$ ) was also influenced by the chitosan application (Table 2). Further, the differences were highly significant $(\mathrm{P}<0.01)$ among the treatments with and without chitosan. Additionally, the maximum 1000-grain weight (g) were recorded when the plant was subjected to the foliar application of $10 \mathrm{~g} \mathrm{~L}^{-1}$ chitosan at the tillering stage. The number of grains per spike was also affected significantly $(\mathrm{P}<0.01)$ by the chitosan application (Table 2). The maximum number of grains per spike was collected with the foliar application of $10 \mathrm{gL}^{-1}$ chitosan at the tillering stage. These results are in accordance with other investigations, which revealed that the chitosan treatment significantly enhanced the number of grains per spike and grain yield to that in control (Behboudi et al., 2018). On the other hand, 1000 grain weight (g) was also affected by the chitosan application (Table 2). Further, the differences were highly significant $(\mathrm{P}<0.01)$ among the treatments with and without chitosan. Moreover, the maximum 1000-grain weight (g) were recorded when the plant was subjected to foliar application of $10 \mathrm{gL}^{-1}$ chitosan at the tillering stage. Behboudi et al. (2018) observed the maximum 1000-grain weight with the foliar treatment of chitosan in the well-watered plant also they noticed that the chitosan application in soil considerably improved the 1000-grain weight in plants under water stress than that of control. Dzung et al. (2017) observed the enhanced growth and fruit yield following the foliar application of oligochitosan in Capsicum frutescens L. Rahman et al. (2018) concluded in his study that foliar treatments of chitosan significantly enhanced the plant growth and fruit yield (up to $42 \%$ more) to that of the untreated control in the strawberry plants. Improved fruit yield was due to the increased plant growth, particularly the fruit weight and total fruit weight per plant, because of the chitosan application. 
However, the spike length was also found affected significantly $(\mathrm{P}<0.01)$ by the application of chitosan (Table 3 ). The maximum spike length (cm) was recorded when the plants were subjected to the foliar application of $10 \mathrm{gL}^{-1}$ chitosan at the tillering stage. The plant height influenced the chitosan treatment, which was shown in Table 3. The highly significant differences $(\mathrm{P}<0.01)$ were also recorded among the treatments with and without chitosan application. The maximum (highest) plant height was noted with $10 \mathrm{~g} \mathrm{~L}^{-1}$ chitosan as a foliar treatment at the tillering stage. Abdel-Mawgoud, (2010) reported the enhanced plant height, the number of leaves and the yield in strawberry plants by the foliar application of chitosan. Furthermore, days to heading was not changed by the chitosan use and also no significant differences $(\mathrm{P}<0.01)$ were seen among the plants treated with and without chitosan (Table 3).

Table 3. Phenological traits of barley plants as affected by the fertilizer and chitosan application

\begin{tabular}{|l|c|c|c|}
\hline \multicolumn{1}{|c|}{$\begin{array}{c}\text { Growing } \\
\text { seasons }\end{array}$} & $\begin{array}{c}\text { Spike } \\
\text { length }(\mathrm{cm})\end{array}$ & $\begin{array}{c}\text { Plant height } \\
(\mathrm{cm})\end{array}$ & $\begin{array}{c}\text { Days to } \\
\text { heading }\end{array}$ \\
\hline $2014 / 15$ & 7 & 80.0 & 91 \\
\hline $2015 / 16$ & 6 & 63.3 & 84 \\
\hline LSD $(0.05)$ & 0.5 & 1.5 & 4.0 \\
\hline $\begin{array}{l}\text { Fertilizer } \\
\text { application }\end{array}$ & & & \\
\hline 0 & 6.0 & 66.3 & 90.0 \\
\hline $100 \mathrm{~kg}^{-1}$ DAP & 7.0 & 77.0 & 85.0 \\
\hline LSD (0.05) & 0.5 & 1.7 & $\mathrm{NS}$ \\
\hline $\begin{array}{l}\text { Chitosan } \\
\text { treatment }\end{array}$ & & & \\
\hline Control & 6.5 & 70.0 & 87.5 \\
\hline 5g L-1 chitosan & 6.5 & 71.0 & 87.5 \\
\hline $10 \mathrm{~g} \mathrm{~L}^{-1}$ chitosan & 6.5 & 74.0 & 87.5 \\
\hline LSD (0.05) & $\mathrm{NS}$ & 1.2 & $\mathrm{NS}$ \\
\hline Fert X Chit & $\mathrm{NS}$ & $\mathrm{NS}$ & $\mathrm{NS}$ \\
\hline
\end{tabular}

\section{Effects of DAP and chitosan on protein and starch content}

The effect of the varying chitosan concentration, with and without 100 DAP level, on the protein and starch content was significant. Apparently, the protein and starch content continuously increased along with the level of chitosan and the combination of $100 \mathrm{~kg} \mathrm{ha}^{-1}$ DAP and $10 \mathrm{~g} \mathrm{~L}^{-1}$. Chitosan was found the most effective in the accumulation of both nutrients in comparison to chitosan alone. The highest protein (12.6\%) was accumulated during the growing season 2014/2015 while the highest starch content $(62.3 \%)$ was noted at $100 \mathrm{~kg} \mathrm{ha}^{-1}$ DAP with $10 \mathrm{~g} \mathrm{~L}^{-1}$ chitosan application during another growing season (2015/2016) (Table 4). The impacts of the fertilizer treatment on the protein content plus quality have also been hugely investigated in barley (Selke, 1940; Michael, 1963; Zoschke, 1973). Additionally, Losak et al. (2010) again recorded that the treatment with a high amount of $\mathrm{N}$ showed a remarkable result on the maximum accumulation of several essential and non-essential amino acids. As reported by Song et al. (2012), different levels of nitrogen can control the accumulation of storage protein and amylase content in rice and increased along with the $\mathrm{N}$ supply, resulting in the improved quality of rice grains. Ozturk et al. (2010), observed the increased protein content with higher nitrogen treatment in potato tuber.

\section{CONCLUSION}

The present study demonstrated that the DAP fertilizer and chitosan treatment influenced the yield and nutrient composition of barley in various proportions. The use of $100 \mathrm{~kg} \cdot \mathrm{ha}^{-1} \mathrm{DAP}$ mixed with foliar treatment of $10 \mathrm{~g} \cdot \mathrm{L}^{-1}$ chitosan

Table 4. Accumulation of protein and starch content (\%) by the fertilizer and chitosan application

\begin{tabular}{|c|c|c|c|c|c|}
\hline \multirow{2}{*}{ Fertilizer application } & \multirow{2}{*}{$\begin{array}{l}\text { Chitosan } \\
\text { treatments }\end{array}$} & \multicolumn{2}{|c|}{$\begin{array}{c}\text { Growing seasons } \\
2014 / 15\end{array}$} & \multicolumn{2}{|c|}{$\begin{array}{c}\text { Growing seasons } \\
2015 / 16\end{array}$} \\
\hline & & Protein content $(\%)$ & Starch content (\%) & Protein content $(\%)$ & Starch content $(\%)$ \\
\hline \multirow{3}{*}{$0 \mathrm{~kg}$} & 0 & 11.0 & 60.0 & 10.8 & 60.4 \\
\hline & $5 \mathrm{gL}^{-1}$ chitosan & 11.2 & 60.1 & 10.9 & 60.5 \\
\hline & $10 \mathrm{gL}^{-1}$ chitosan & 11.5 & 60.4 & 11.0 & 60.6 \\
\hline \multirow{3}{*}{$100 \mathrm{~kg} \mathrm{ha}^{-1}$ DAP } & $\begin{array}{l}\text { Chitosan } \\
\text { treatment } 0\end{array}$ & 12.4 & 60.4 & 11.4 & 60.7 \\
\hline & $5 \mathrm{gL}^{-1}$ chitosan & 12.5 & 62.0 & 12.0 & 62.3 \\
\hline & $10 \mathrm{gL}^{-1}$ chitosan & 12.6 & 62.1 & 12.1 & 62.3 \\
\hline LSD & & 0.7 & 0.6 & 0.8 & 0.5 \\
\hline
\end{tabular}


on barley that were grown under the semi-arid condition resulted in the highest grain yield, yield component and phenological traits during both growing seasons. Additionally, the protein and starch content were elevated by the same treatment level of DAP and chitosan when plants were faced the water stress condition.

\section{REFERENCES}

1. AACC, 2000. Approved methods of the AACC (10 ed.). St. Paul, MN, USA.

2. Abdel-Mawgoud A. Tantawy M.R. El-Nemret A.S. Sassine M.A. Y.N. 2010. Growth and yield responses of strawberry plants to chitosan application. Eurasian Journal of Scientific Research, 39: 170-177.

3. Abera T. Molla A. Feyissa A. Liben M. Woyema A. Admassu L. Bekele A. 2011. Research achievements in barley cultural practices in Ethiopia. Barley Research and Development in Ethiopia. Proceedings of the 2nd National Barley Research and Development Review Workshop: 113.

4. Al-Ajlouni M.M. Al-Ghzawi A.A. Al-Tawaha A. M. 2009. Crop rotation and fertilization effect on barley yield grown in arid conditions. Journal of Food Agriculture and Environment, 88: 869-872.

5. Al-Tawaha A.M. Al-Ghzawi A.M. 2013. Response of barley cultivars to Chitosan application under semi-arid conditions. Research on Crops, 14: 427-430.

6. Al-Tawaha A.M. Turk M.A. Maghaereh G.A. 2002. Response of barley to herbicide versus mechanical weed control under semi-arid conditions. Journal of Agronomy and Crop Science, 188: 106-112.

7. Al-Tawaha A.M. Seguin P. Smith D.L. and Beaulieu C. 2006. Foliar application of elicitors alters isoflavone concentrations and other seed characteristics of field-grown soybean. Canadian Journal of Plant Science, 86: 677-684.

8. Al-Tawaha A.M. Singh V.P. Turk M.A. Zheng W. 2003. A review on growth, yield components and yield of barley as influenced by genotypes, herbicides and fertilizer application. Research on Crops, 4: 1-9.

9. Al-Tawaha A.M. Turk M.A. 2002. Awnless barley (Hordeum vulagre L.) response to hand weeding and 2,4-D application at two growth stages under Mediterranean environment. Weed Biology and Management, 2: 163-168.

10. Asare E.K. Jaiswal S. Maley J. BåGa J. Sammynaiken M.R. Rossnagel B. Chibbar R.N. 2011. Barley grain constituents, starch composition, and structure affect starch in vitro enzymatic hydrolysis. Journal of Agriculture and Food Chemistry, 59: 4743-4754.
11. Baik B. K. Ullrich S. E. 2008. Barley for food: characteristics, improvement, and renewed interest. Journal of Cereal Science, 48: 233-242.

12. Behboudi F. Tahmasebi Z. Sarvestani M. Zaman Kassaee S.A.M. Modares Sanavi A. Sorooshzadehand S.B. Ahmadi. 2018. Evaluation of Chitosan Nanoparticles Effects on Yield and Yield Components of Barley (Hordeum vulgare L.) under Late Season Drought Stress. Journal of Water and Environental Nanotechnology, 3: 22-39.

13. Bittelli M. Flury M. Campbell G.S. Nichols E.J. 2001. Reduction of transpiration through foliar application of chitosan. Agriculture and Forest meteorology, 107: 167-175.

14. Brown D. Weselby. 2010. NASA-funded research discovers life built with toxi chemical NASA Feature, NASA December, www.nasa.gov.

15. Chamnanmanoontham N. Pongprayoon W. Pichayangkura R. Roytrakul S. Chadchawan S. 2015. Chitosan enhances rice seedling growth via gene expression network between nucleus and chloroplast. Plant Growth Regulation, 75: 101-14.

16. Chandrkrachang S. 2002. The application of chitin and chitosan in agriculture in Thailand. Advances in Chitin and Chitosan Science, 5: 458-462.

17. Doares S.H. Syrovets T. Weilerand C E.W. Ryan A. 1995. Oligogalacturonides and chitosan activate plant defensive genes through the octadecanoid pathway. Proceedings of the National Academy of Sciences of the United States of America, 92: 4095-4098.

18. Dzung P.D. Phu D.V. Du B.D. Ngoc L.S. Duyand N.N. DHiet H. 2017. Effect of foliar application of oligochitosan with different molecular weight on growth promotion and fruit yield enhancement of chili plant. Plant Production Science, 20: 389-395.

19. Farouk S. Ghoneemand K.M. Ali A. Abeer M. 2008. Induction and expression of systematic resistance to downy mildew disease in cucumber plant by elicitors. Egyptian Journal of Phytopathology, 1: 95-111.

20. Garcia-Lorda P. Megias-Rangiland I. Salas-Salvado J. 2003. Nut consumption, body weight and insulin resistance. European Journal of Clinical Nutrition 57, suppl. 1, S8-S11.

21. Górnik K. Grzesik M. and Romanowska-Duda B. 2008. The effect of chitosan on rooting of grapevine cuttings and on subsequent plant growth under drought and temperature stress. Journal of Fruit and Ornamental Plant Research, 16, 333-43.

22. He Z. 1985. Grain Quality and Its Analysis Technology. (Beijing: Agriculture press, 1985).

23. Huang C.Y., Shirley N., Genc Y., Shiand B. Langridge P. 2011. Phosphate utilization efficiency correlates with expression of low-affinity phosphate 
transporters and noncoding RNA, IPS1, in barley. Plant Physiology, 156: 1217-1229.

24. Kim H.J. 2005. Characterization of bioactive compounds in essential oils, fermented Anchovy sauce, and edible plants, and, induction of phytochemicals from edible plants using methyl jasmonate (MeJA) and chitosan. PhD Thesis, Clemson University, USA, $178 \mathrm{pp}$.

25. Marschner H.1999. Mineral nutrition of higher plants. Academic press. London, 889p.

26. Michael G.1963. Einfluss der Diingung auf Eiweissqualitat und Eiweissfraktionen der Nahrungspflanzen. Qual. Plant. Mat. Veget. 10, 253-265.

27. Mondal M. Putehand A.B. Dafader N.C. 2016. Foliar Application of Chitosan Improved Morphophysiological Attributes and Yield In Summer Tomato (Solanum Lycopersicum). Pakistan Journal of Agricultural Sciences, 53(2).

28. Nursu'aidah H. Motior M.R., Nazia A.M. Islam M.A.. 2014. Growth and photosynthetic responses of long bean (Vigna unguiculata) and mung bean (Vigna radiata) response to fertilization. Journal of Animal and Plant Sciences. 24: 573-578.

29. Orgaz B. Lobete M.M. Puga C.H. San Jose C. 2011. Effectiveness of chitosan against mature biofilms formed by food related bacteria. International of Molecular Sciences, 12: 817-828.

30. Rahman M. Mukta J.A. Sabir A.A. Gupta D.R. Mohi-Ud-Din M. and Hasanuzzaman M. 2018. Chitosan biopolymer promotes yield and stimulates accumulation of antioxidants in strawberry fruit. PLoS ONE, 13(9).

31. Rowley H.V., Peters G.M., Lundieand S. S. Moore J. 2012. Aggregating sustainability indicators: beyond the weighed sum. Journal of Environmental Management, 111: 24e33.

32. Sharathchandra R.G. Raj S.N. Shetty N.P. Amruthesh K.N. Shetty H.S. 2004. A Chitosan formulation Elexa induces downy mildew disease resistance and growth promotion in pearl millet. Crop Protection, 23: 881-8.

33. Steel R.G.D. Torrie J.A. 1980. Principals and Procedure of Statistics. 2nd Edn. Mc. Graw-Hill.
Switzerland, pp. 687.

34. Tawaha A. M. and Turk M.A. 2002a. Lentil (Lens culinaris Medic.) productivity as influenced by and method of phosphate placement in a Mediterranean environment. Acta Agronomica Hungarica, 50: 197-201.

35. Tawaha A.M. 2000. Evaluation of Ten Barley Genotypes in Response to Fertilization and Herbicide Application). M.Sc. Jordan University of Science and Technology, Irbid, Jordan.

36. Tawaha A.M. Turk M.A. 2004. Field Pea Seeding Management for Semi-arid Mediterranean conditions. Journal Agronomy and Crop Science, 190, 86-92.

37. Tawaha A.M. Turk M.A. Maghaereh G.A. 2002. Response of Barley to herbicide versus mechanical weed control under semi-arid conditions. Journal Agronomy and Crop Science, 188, 106-112.

38. Tawaha A.M. Singh V.P. Turk M.A. Zheng W. 2003. A review on growth, yield components and yield of barley as influenced by genotypes, herbicides and fertilizer application. Research on Crops, 4: 1-9.

39. Terán H. and Singh S.P. 2002.Comparison of Sources and Lines Selected for Drought Resistance in common Bean Published as Idaho Agric. Exp. Stn. Journal Article No. 01722, Univ. of Idaho, College of Agriculture and Life Sciences, Moscow, ID 83844. Crop Science 42(1),64-70.

40. Turk A.M. Tawaha A.M. 2002. Onion (Allium cepa L.) as influenced by rate and method of phosphorus placement. Crop Research, 23: 105-107.

41. Turk M.A, Tawaha A. M. Samara N. 2003. Effects of seeding rate and date, and phosphorus application on growth and yield of narbon vetch (Vicianarbonensis). Agronomy Journal, 23: 1-4

42. Turk M.A. Tawaha A.M. 2001. Common vetch (Vicia sativa L.) productivity as influenced byrate and method of phosphate fertilization in a Mediterranean environment. Agric. Mediterr.131: 108-111.

43. Turk M.A. Tawaha A.M. Lee K.D. 2004. Seed Germination and Seedling Growth of Three Lentil Cultivars under Moisture Stress. Asian Journal of Plant Sciences, 3: 394-397. 